\title{
ELMÉLETEK, ELKÉPZELÉSEK \\ A TANÁRI PROFESSZIONALIZMUSRÓL ÉS KÖVETKEZMÉNYEIRŐL A TANÁRKÉPZÉSI PROGRAMOK TARTALMÁRA
}

\section{MARCO SNOEK}

az Amsterdam Institute of Education egyetemi docense

M.Snoek@hva.nl

\begin{abstract}
A tanároknak igen vegyes elvárásoknak kell megfelelniük. Egyrészt a tanári munkával szemben támasztott minimális szakmai sztenderdeknek. A tanári munka minősége miatti aggodalmak oda vezettek, hogy a minimum sztenderdeknek és a tanári munka tudásbázisának szigorúbb és pontosabb fogalmazására került sor. Másrészt a társadalom egyre magasabb elvárásokat támaszt a tanárok szakmaiságával kapcsolatban. A professzionalizmus kiterjesztett definíciója és a tanárok élethosszig tartó tanulása mind az egyes nemzetállamokban, mind Európában a viták középpontjában áll (European Council, 2009). A viták azt a problémát vetik fel, hogy vajon a tanárképzés megfelelően felkészíti-e a tanárokat arra, hogy a megnövekedett elvárásoknak meg tudjanak felelni.

E kérdés megválaszolásához tisztáznunk kell, hogy az új elvárások milyen tanári tulajdonságok kialakitását teszik szükségessé. Ebben a cikkben pontosan erre teszek kísérletet: a szakmával szembeni megnövekedett elvárások áttekintése nyomán megpróbálom összegyüjteni azokat a tanári tulajdonságokat, amelyekkel az új tanárgenerációnak rendelkeznie kell, ha meg akar felelni a kihívásoknak. A kihívásokat, az elvárásokat az utolsó évtizedben a tanári professzionalizmus témájában megjelent szakirodalom alapján tekintem át. Az áttekintés eredményeként kialakított tulajdonságlista eddig csekély figyelmet kapott a már megjelent sztenderdekben és tanárképzési tantervekben. A tanárképzés felelőssége az, hogy a társadalom elvárásaihoz igazítsa a képzés tartalmát, tantervét és egy „kiterjesztett” tanári szerepre készítse fel a tanárjelölteket.
\end{abstract}

\section{A tanároktól elvárt tulajdonságok}

A szakirodalom a tanárokat tartja a tanulói teljesítményekre legnagyobb hatást gyakorló iskolai tényezőnek. A „Hogyan kerülnek élre a világ legjobban teljesítő 
iskolarendszerei” "ímü McKinsey jelentés erről így fogalmaz: „A rendelkezésre álló adatok azt bizonyítják, hogy a tanulói teljesítmények között fennálló különbségek legfontosabb oka a tanári munka minősége." (Barber és Mourshed, 2007, 12. o.). Egy nagymintás felmérés alapján, amely a tanulói munka minőségét befolyásoló tényezőket vizsgálta (Hattie, 2009), megállapítható, hogy a tanári munka minőségének nagyobb hatása van a tanulói teljesítményekre, mint a tantervnek, a tanítási módszereknek, az iskolai infrastruktúrának vagy a szülöknek. Széles körben elfogadott, hogy a tanári munka minősége döntő fontosságú, és ez magyarázza, hogy a tanári munka minőségét célzó politikák mind nemzetállami, mind európai szinten a figyelem középpontjában állnak. Az Európai Tanács és az Európai Bizottság olyan politikai állásfoglalásokat és ajánlásokat fogalmazott meg, amelyek a tanári minőség és a tanárképzés minőségének jobbítását szorgalmazzák, és arra ösztönzik a nemzeti kormányokat, hogy fektessenek be a tanári munka minőségének javításába (European Commission, 2005, 2007; European Council, 2007, 2009).

A nemzeti kormányoknak be kell fektetniük a tanári munka színvonalának emelésébe, mert oktatási rendszereik jelentős kihívásokkal néznek szembe. A társadalmi változások új kihívások elé állítják az iskolákat. Egy $\mathrm{CEDEFOP}^{2}$ tanulmány bemutatja, milyen változások várhatók az európai munkaerőpiacon, hogyan kerül át a foglalkoztatás az elsődleges szektorokból, főleg a mezőgazdaságból és a hagyományos ipari szektorból a szolgáltató iparba és a tudásiparba (knowledge intensive jobs; $C E D E F O P$, 2008). A társadalmi változások és az az igény, hogy a társadalmi stabilitást befektetések árán is megőrizzék, az élethosszig tartó tanulás kulcskompetenciának újrafogalmazásához vezetett (European Council, 2006). Ezek olyan transzverzális kompetenciákat foglalnak magukban, mint a digitális kompetencia, a tanulási kompetenciák, a szociális és állampolgári kompetenciák, a kezdeményezőkészség és a vállalkozói kompetencia, a kulturális tudatosság és a kifejezőkészség. A középiskolai oktatásban az inklúzív oktatás és a kompetenciaalapú tanterv középpontba helyezése a személyre szabott, adaptív tanításra és tanulásra irányította a figyelmet $(O E C D, 2007)$.

Mindezek a változások az iskolai tantervek és a tanárok napi munkájának erőteljes átalakítását követelik meg. És bár a tanárok a változások bevezetésének kulcsfigurái, az átalakítás nem az egyes tanárok, hanem az iskolai tantestületek felelőssége. Ezért a fő hangsúly olyan fogalmakon van, mint a szakmai tanulási közösségek (professional learning communities), a kollaborativ tanulás, az iskolavezetés és az innovációs stratégiák.

A tanulási teljesítmények növelését úgy kell elérni, hogy közben a rendelkezésre álló erőforrások korlátozottak maradtak, ezért megnövekedett az érdeklődés

\footnotetext{
${ }^{1} \mathrm{http} / /$ ssomckinsey.darbyfilms.com/reports/schools/How-the-Worlds-Most-Improved-School-SystemsKeep-Getting-Better_Download-version_Final.pdf Letöltés ideje: 2011. 07. 27.

${ }^{2}$ European Centre for Development of Vocational Training
} 
az olyan tanítási/oktatási gyakorlatok, módszerek iránt, amelyeknek az eredményessége bizonyítható. A tanárokat elkezdték tudásmunkásoknak tekinteni, akik aktív szerepet játszanak a bizonyítékokra épülő szakmai tudás kialakításában, fejlesztésében kutatási és önképzési tevékenységük révén.

A tanárokkal és a tanári szakmaisággal szemben támasztott társadalmi elvárások hatalmasak. A tanároktól magasabb szintủ szakmaiságot vár el a társadalom (Stenhouse, 1975), kiterjesztett szerepelvárásoknak kell megfelelniük. A tanári szerep tágabb, kiterjesztett felfogása megjelenik abban a TALIS felmérésben is, amely a tanári továbbképzésekkel foglalkozott: „A tanári továbbképzések tartalmi elemei között olyan tartalmak jelentek meg, amelyek többé-kevésbé integráltak a tanárok mindennapi tevékenységébe, és amelyek a tanári szerepeknek egy szélesebb spektrumát fogják át: a tanítás mellett hangsúlyozzák a tanárok modern szakmai közösségekben, szervezetekben betöltött szerepét. Ezen elemek között gyakran szerepelnek olyan fogalmak, mint a reflektív gyakorló szakember, az iskola, mint tanuló szervezet és a tanárok másodlagos folyamatokban betöltött szerepe. A másodlagos szerepek erőteljesebb hangsúlyozása része a szakma modernizációjának. Ilyen $m a ́$ sodlagos szerepek: a gyakorló tanár, mint kutató, mint a kollegiális visszacsatolás alanya, mint innovátor, mint aktív kolléga, mint az igazgató munkájának segítője, mint tanári vezető (teacher leadership)". (European Commission, 2010. 191. o.)

Felvetődik a kérdés, mennyire készíti fel a tanárképzés a jelölteket ezeknek az új, másodlagos szerepeknek az ellátására. Ahhoz, hogy meg tudjuk válaszolni ezt a kérdést, górcső alá kell vennünk azokat a tulajdonságokat, amelyek a kiterjesztett tanári szerep sikeres vállalásához szükségesek. A másodlagos tanári szerep sok rokonságot mutat a Stenhouse és Hoyle által megalkotott kiterjesztett professzionalizmus (szakmaiság) fogalmával (Hoyle, 1975; Stenhouse, 1975,) ezért a kérdés megválaszolásához áttekintem az utóbbi évtized tanári professzionalizmusról szóló szakirodalmát.

Elöször röviden bevezetem a szakmaiság (professzionalizmus) fogalmát, majd az irodalomban fellelhető öt perspektívából tárgyalom a fogalmat. A cikk végén az irodalmi összefoglaló alapján listába foglalom a professzionális tanárok legfontosabb tulajdonságait. Ennek a listának a fényében lehet majd a tanárképzési tanterveket elemezni, megállapítani, vajon felkészítik-e a jelölteket a tanári pálya professzionális müvelésére, valamint fel lehet térképezni, hogy mely pontokon szorulnak az egyes tantervek javításra annak érdekében, hogy jobban szolgálják a tanárjelöltek felkészítését a szakmai életre.

\section{A tanári professzionalizmus elemzése}

Az értelmiségi szakmák és szakmaiság kutatása a 20. század elején kezdődött és azóta is elfogadott témája a szociológiai kutatásoknak (Evetts, 2006; Crook, 2008). A szociológusok régóta próbálják azonosítani azokat az értékeket, amelyek az értelmiségi szakmákhoz kapcsolhatók, és ugyanakkor megpróbálják azonosítani azo- 
kat a kritériumokat, amelyek elválasztják az értelmiségi szakmákat más foglalkozásoktól. Mivel az értelmiségi szakmákkal és szakmaisággal kapcsolatos vitákban az értelmiségi szakmákhoz általában pozitív sajátosságok és presztízselemek kötődnek, sok foglalkozás próbálta/próbálja magát értelmiségi szakmaként meghatározni, hogy az elit része lehessen.

Ez a tanárságra is vonatkozik. Sok olyan tanárokkal kapcsolatos publikáció jelenik meg, amelyben a tanárok megjelölésére szándékosan az oktatási szakember megjelölést használják, hogy ezzel is jelezzék és hangsúlyozzák a tanárság magas presztízsét és státuszát. A tanársággal kapcsolatos szakmapolitikai dokumentumok tele vannak olyan megfogalmazásokkal, mint szakmai sztenderdek, szakmai fejlödés, szakmai közösségek stb. Sok ilyen publikációban azonban nem világos, hogy a tanári szakmaiság fogalma a jelen státusz quo leírása, vagy inkább egy olyan ideál, amely felé érdemes lenne törekedni. Ez pedig oda vezet, hogy a szakma és a szakmaiság fogalma diffúz, nem világosan definiált.

Ebben a tanulmányban a szakma és a szakmaiság meghatározására a következő definíciókat fogom használni Evetts (2009), Koster (2002) és Hargreaves (2000) nyomán:

- Értelmiségi szakma: a foglalkozások egy meghatározott kategóriája.

- Értelmiségi szakmává válás: olyan folyamat, amelynek során egy foglalkozási csoport kifejleszti, elsajátítja és fenntartja a szakmaiság fó vonásait.

- (Értelmiségi) szakmaiság: azok a viselkedések és sztenderdek, amelyek egy szakma képviselőinek munkáját megszabják, irányítják.

Az elmúlt század folyamán az értelmiségi szakmákról és a tanári szakmaiságról szóló szociológiai diskurzus többféle és változó perspektívából vizsgálta a kérdést, a szakmaiság különféle aspektusait hangsúlyozva (Evetts, 2006). Irodalmi áttekintésünkben öt ilyen perspektívát találtunk.

\section{Östípusok /ideáltipusok (archetypes) és attribútumok}

A tanárok szakmaiságának vizsgálatakor az egyik lehetséges út az, hogy összehasonlítjuk a tanárságot a klasszikus értelmiségi professziókkal, az orvosi és a jogászi szakmával, ennek során rámutatunk a hasonlóságokra és a különbözöségekre. Ha a klasszikus értelmiségi professziókat ideáltípusoknak tekintjük, meg lehet állapítani, melyek azok a tipikus vonások, amelyek az értelmiségi szakmákra jellemzőek, és így el lehet választani az értelmiségi szakmákat azoktól a foglalkozásoktól, amelyek nem minősülnek értelmiségi szakmáknak, és be lehet határolni az értelmiségi szakmák és más foglalkozások közötti hasonlóságokat és azonosságokat. Ebben a megközelítésben a fö hangsúly a foglalkozások osztályozásán, a foglalkozási kategóriák meghatározásán van (Gewirtz et al., 2009). A foglalkozások ilyen osztályozása során a klasszikus értelmiségi professziókat az igazi értelmiségi szakmák őstípusaiknak, ideáltípusainak (archetypes) tekintik. 
Az értelmiségi szakmák tipikus jellemzői a következők (Snoek, Swennen és Van der Klink, 2009):

- Szakmai autonómia: a szakmához tartozók monopóliummal bírnak a szakma felett, saját munkájukat teljes mértékben ök maguk kontrollálják.

- A szakmához tartozók ellenőrzik a szakmába történő belépés követelményeit, és az egyes tagok szakmai előmenetelét, fejlődését. A szakmához tartozók döntik el, hogy a szakmához tartozók adott esetekben a szakmai sztenderdeknek és a szakma etikai kódexének megfelelően jártak-e el, ezzel együtt jogukban áll a döntés alapján kizárni a szakmából azokat, akik vétettek a szabályok ellen.

- A szakma megalkotja etikai kódexét, amely segítségével megnyeri a nyilvánosság és azon köztestületek (sokszor kormányok) bizalmát, amelyek a szakmának és müvelőinek kiadják a müködési engedélyt. A szakma etikai kódexe meghatározza a szakmailag elfogadható viselkedés normáit.

- Tudományos megalapozottság (a strong academic knowledge base; Abbott, 1988), elméleti vagy technikai tudás (Goodson, Hargreaves, 1996). „A tudományos megalapozottság legitimálja a szakma tevékenységét és összeköti a szakmát az alapvető kulturális értékekkel. A legtöbb modern értelmiségi szakmában ezek az értékek: a racionalitás, a logika és a tudományosság. A tudós értelmiség (academic professionals) képviseli a szakmai munka szigorúságát, világosságát, tudományos és logikus jellegét" (Abbott, 1988, 54. o.).

- Szakmai szabadság: a szakma tagjait nem valaki foglalkoztatja, nem állásban vannak, hanem függetlenek és önfoglalkoztatók.

Ha a tanári szakmát összevetjük a klasszikus értelmiségi szakmák jellemzőivel, akkor világosan látszik, hogy a tanárság nem tekinthető igazi szakmának. A tanárok nem kontrollálják, ki léphet be a szakmába, nem függetlenek, hanem az iskolák foglalkoztatják öket. Ezért a tanároknak csak korlátozott autonómiájuk van. Sok országban a tanárság nem is rendelkezik etikai kódexszel. A tanári szakma tudományos megalapozottságát sok szerző gyengének tartja (Verbiest, 2007). Még ma is kevés tanárnak van kutatói képzettsége, és kevesen végeznek posztgraduális tanulmányokat (Erixon, Frånberg és Kallós, 2001). Ennek következtében a tanári szakmát az ápolással, a szociális munkával és a könyvtárossággal együtt, gyakran nevezik szemiprofessziónak, vagyis félszakmának (semi-profession; Etzioni, 1969).

Bár tény, hogy a klasszikus professziókkal történő összevetést a szakmaiságról szóló vitákban gyakran alkalmazzák, ezt a megközelítést sokan kritizálják is. Az így meghatározott szakmaiságot sokan mesterséges konstrukciónak gondolják, amelynek definíciója folyamatosan viták tárgya (Crook, 2008), és állandóan változik, attól függően, hogy éppen ki, mit gondol róla (Hanlon, 1998). Sokan úgy vélik, hasznosabb a tanári professzió mai jellemzőit feltárni, mint a szakmát valamiféle ideáltípushoz hasonlítani (Whitty, 2008). 
A szakma professzionalizálása projekt

A szakmaiság második megközelítési módja a professzionalizálási projekt (Larson, 1977), amelynek az a célja, hogy kialakítson egy olyan szakmai testületet, amely ellenőrzi és megnehezíti a szakmába történő bejutást, ezzel olyan monopolhelyzetet teremt, amelynek segítségével a szakma meg tudja őrizni minőségét, és biztosítani tudja, hogy részt vehessen a hatalomról, a befolyásról, a státuszról szóló vitákban, a munkakörülményekről és a szakmai autonómiáról szóló alkukban. Ebből a perspektívából már nem számít a szakmaiság ideáltípusa, amely referenciakeretként behatárolja, hogy mely szakmák nevezhetik magukat szakmának. A hangsúly egy foglalkozási csoport növekvő öntudatán van, amely a szakmai rang elnyerését tüzte ki célul (Power, 2008).

E folyamat középpontjában a szakma tudásbázisának kialakitása áll: a szakmai munka sztenderdjeinek megállapítása és emelése, a szakmába történő jogosulatlan belépés megakadályozása, az önellenőrzés és önelszámoltathatóság mechanizmusainak kialakítása, és azoknak az etikai normáknak a lefektetése, amelyek a szakma erényeit hivatottak megtestesíteni. Efféle professzionalizálódási folyamatnak több szakmában is tanúi lehettünk. Ezek a szakmák megalkották saját szakmai társaságaikat, folyóirataikat, etikai kódexeiket, mint például az újságírók (Crook, 2008) vagy a holland tanárképzők (Koster, 2002). Hasonló folyamat egy stációjának tekinthető a holland tanárok szakmai jegyzékének jelenleg folyamatban levő létrehozása is. Ebben a megközelítésben a klasszikus professziók nem egy adott szakma szakmaiságának eldöntése során szolgálnak referenciaként, hanem egy adott szakma szakmává fejlődése során.

A professzionalizálódási projektről szóló vitákban két különböző perspektíva bukkan fel. Az egyik a szakma idealista koncepcióját konstruálja meg és a szakma képviselőinek specialista voltát, valamint etikai erényeit hangoztatja, például a megbízhatóságot, a kollegialitást, a társadalmi szolgálatot. A másik megközelítés a szakma önérdekét fogalmazza meg, tehát a piac monopolizálását, a státuszt és a hatalmi érdeket (Larson, 1977), ami végül is a kormányokkal történő tárgyalásokhoz és alkukhoz vezet a szakma hatásköréröl (professional mandates), befolyásáról, a munkakörülményekröl és arról, hogy a szakmai munka megítélése milyen jogi fórum alá tartozzék (jurisdictional competition; Gewirtz et al, 2009). Az idealista elképzelés hozzájárulhat a szakma iránti társadalmi bizalom növeléséhez, míg a másik koncepció könnyen csökkentheti azt.

\section{A modern társadalom magas követelményei}

A tanári professzionalizmust a mai modern, versenyre épülő társadalmak magas elvárásainak perspektívájából is meg lehet ragadni. A mai posztmodern és neoliberális társadalmakat erőteljes gazdasági és technológiai változások jellemzik. A gazdasági változások a professzionalizmus erösen globalizált, piacorientált és versenyszel- 
lemü megközelítését eredményezték, a szakmák erősebb központi szabályozásának igényével együtt (Gewirtz et al, 2009). Az állandóan változó, piacorientált kontextus nem csak az iskolavezetőkkel, hanem a tanárokkal szemben fennálló elvárásokat is megváltoztatta: egyre inkább középpontba kerültek olyan fogalmak, mint az elszámoltathatóság, a racionalitás, a versenyképesség és a kontroll (Evans, 2008; Goodson és Hargreaves, 1996; Robertson, 1996). Hargreaves erről így írt: „Az iskolákat, hasonlóan más közfunkciót ellátó intézményekhez, racionalizálták, büdzséjüket megnyirbálták, gazdasági hatékonyságukat növelték, hogy minél kevésbé jelentsenek terhet az adófizetőknek, és versenyeztetni kezdték őket egymással a 'kliensekért'”. (Hargreaves, 2000, 168. o.)

Ez a megközelítés gyakran használja az új professzionalizmus fogalmát, jelezve, hogy a megváltozott körülmények között a szakmaiság nevében a tanároktól új kvalitásokat várnak el: a hangsúly a hatékonyságon, az elszámoltathatóságon, a nemzeti (állami szintü) minöségbiztositáson és kontrollon van. Kissé részletesebben:

- A legfontosabb elvárás a minőségi munka és a kimeneti követelmények teljesítése.

- Fontos a társadalmi elszámoltathatóság, tehát a tanároknak el kell magyarázniuk, hogy a tanításuk miként szolgálja a kimeneti követelmények teljesítését.

- Olyan szakmai sztenderdeket fektetnek le és vezetnek be, amelyek leírják, mit kell tudnia egy kezdő és mit egy szakértő tanárnak.

Az OECD szempontjából elsőbbséget élvez a sztenderdek kialakítása: „Az országok számára az egyik legfontosabb prioritás olyan világos és tömör megfogalmazások, profilok megalkotása, amelyek leírják, hogy a tanároknak mit kell tudniuk, és mit kell tudniuk megcsinálni. Ezekre a profilokra azért van szükség, hogy keretet biztosítsanak a tanárképzés, a tanárképesítések, a tanári továbbképzések és a tanári szakmai előmenetel rendszerei számára, hogy segítségükkel meg tudjuk ítélni, hogy e rendszerek egyes elemei jelenleg mennyire hatékonyak." $(O E C D, 2005,131$. o.)

Az elmúlt időszakban e sztenderdek nagy részét a nemzeti kormányok a tanárok minimális bevonásával, vagy teljesen nélkülük dolgozták ki (Snoek et al, 2009). Az új professzionalizmus ellen föleg Angliában fogalmazódtak meg olyan érvek, hogy éppenséggel a szakma deprofesszionalizálásához vezet és túlhangsúlyozza a menedzsment szerepét (Whitty, 2008; Hargreaves, 2000).

Ugyanekkor, a tudásalapú társadalom (knowledge society) és a technológiai változások, amelyek az információt és a szórakozást egyaránt globálisan és azonnal elérhetővé tették, a modern professzióktól más vonások kifejlesztését is megkövetelik (Hargreaves, 2000):

- Egyre fontosabbá válik az értelmiségi szakmákban az egész életen át tartó tanulás. Általánosan elfogadottá vált, hogy tudásigényes társadalmunkban az élethosszig tartó tanulás a teljes szakmai életutat átfogó fejlődés záloga. (European Council, 2009; ETUCE, 2008). 
- A kollégákkal, a tanulókkal és szüleikkel új típusú kapcsolatokat és együttmüködést kell kialakítani (Hargreaves, 1994, 424. o.). Whitty (2008) nem csak az együttmüködő professzionalizmus fontosságát hangsúlyozza, amely az egy iskolában tanítók szakmai tanuló közösségeiben valósulhat meg, hanem a demokratikus professzionalizmust is hirdeti, amely az iskolán kívüli, de az iskolai életben érdekelt felek között valósulhatna meg.

- A minőség javítása és az innováció szintén hangsúlyos szerepet kap: a tanítást, mint dinamikus és innovatív professziót írják le, amelyben a tanároknak reflektálniuk kell a gyakorlatukra, és hozzá kell járulniuk a szakma munkájának állandó javulásához, megújulásához.

A tanári professzió tudásbázisa tehát kutatás, tapasztalat és reflexió útján alakul ki. A professzionalizmus ilyen felfogása szükségessé teszi, hogy a tanárok bekapcsolódjanak akciókutatásokba, introspektív (önfeltáró) kutatásokba, és azt is, hogy kutassák saját gyakorlatukat (practitioner inquiry; Cochran-Smith - Lytle, 2009; Loughran et al, 2004; Ponte - Smeets, 2009; Stenhouse, 1975).

A versenyre épülő tudástársadalmakban a professziókra jellemző vonások közül egyrészt az élethosszig tartó együttműködő tanulást és az innovációt hangsúlyozzák, másrészt az elszámoltathatóságot, amelyet a kimeneti eredmények és a szakmai sztenderdek segítségével megvalósítható minőségellenőrzéssel lehet megoldani.

\section{A professzionalizmus logikája}

A negyedik megközelítés a munkaerő-piaci logikák alapvető különbségeire fókuszál. Bár ez a megközelítés is megkísérli elkülöníteni a professziókat a nem-professzióktól, de nem a szakmák külsődleges vonásaira koncentrál, hogy aztán ezek alapján sorolja öket különböző kategóriákba, hanem arra a mögöttes és sokkal alapvetőbb logikára, amely alapján meg lehet magyarázni, hogy egyes szakmák miért jelennek meg értelmiségi szakmaként, míg mások nem. E területen fontos munkát végzett Freidson (2001).

Freidson három különböző logikáról beszél: a bürokrácia, a szabad piac és a professzionalizmus logikájáról. A dolgozók különböző tulajdonságokat müködtetnek a különbözö logikák mentén felépített rendszerekben.

- A bürokrácia logikája alapján müködtetett rendszerekben a javak és szolgáltatások termelését, elosztását egyaránt nagy szervezetek, így kormányok, privát vállalatok és köztestületek tervezik meg, ellenőrzik és szabályozzák. A bürokrácia fö célja, hogy megbízhatóan müködő, átlátható társadalmat hozzon létre, amelyben mindenkinek azonos jogai vannak, mindenki hozzáfér a javakhoz és a szolgáltatásokhoz. A szabályok biztosítják, hogy mindenki azonos elbánásban részesüljön, ne kelljen személyes kapcsolataira támaszkodnia. Minden szervezet munkáját alaposan kidolgozott szabályrendszer irányítja, amely elöírja, hogy milyen kvalifikáció- 
val kell rendelkezniük az egyes munkakört betöltőknek, és meghatározza a munkaköri kötelezettségeiket is. A tervezés, a minőségbiztosítás és a sztenderdizálás biztosítja, hogy a vevők mindenütt megbízható szolgáltatásokhoz jussanak ésszerủ árakon. Ezt azok a menedzserek biztosítják, akik ellenőrzik és szabályozzák a terméket előállítók munkáját.

- A szabad piac alapján müködtetett rendszerben mindenki szabadon ad és vesz árucikkeket és szolgáltatásokat. Semmit sem szabályoznak, a vásárlók racionális döntéseket hoznak anyagi és érzelmi megfontolások alapján, valamint azon az alapon, hogy milyen előzetes tapasztalatokat szereztek az árucikkekkel, a szolgáltatásokkal és a szolgáltatókkal kapcsolatban. A szabad és szabályozatlan verseny letöri az árakat és ösztönzi az innovációt. A vásárlóknak a minőségre és az árakra vonatkozóan átlátható információi vannak, s az ezek alapján kialakított vásárlói elégedettség, preferencia és választás szabja meg, hogy melyik árú, illetve kinek a szolgáltatása lesz sikeres.

- A professzionalizmus logikája szerint azok a munkavállalók, akik speciális tudással rendelkeznek, felhatalmazást kapnak arra, hogy maguk szervezzék meg munkájukat. Az ő privilégiumaik kizárólagosak, sem a vevők, sem a menedzserek nem foglalkoztathatnak mást a munkakörükben. A kizárólagosság azzal jár, hogy maga a szakma kontrollálja magát és akadályozza meg, hogy a szakma bármely tagja visszaéljen a kapott kiváltságokkal. Így a vevők és a menedzserek egyaránt számíthatnak arra, hogy munkájukat magas színvonalon és ésszerü költséghatáron belül végzik.

Freidson megközelítésében a professzionalizmus jól körülhatárolható felhatalmazáshoz kötött, amely szerint: ,,...egy szervezett foglalkozás megszerzi a hatalmat arra, hogy meghatározza, kit tekint kvalifikáltnak bizonyos meghatározott munkafeladatok elvégzésére, és megakadályozza, hogy bárki más elvégezhesse azt a feladatot, és azt is meghatározza, milyen kritériumok alapján lehet valakinek az adott szakmában elvégzett munkáját értékelni. A szervezett professziók olyan körülményeket teremtenek, amelyekben a szakma tagjait nem ellenőrizhetik az őket alkalmazók." (Freidson, 2001, 12. o.)

E harmadik fajta logikára azért van szükség, mert bizonyos munkák olyan specializáltak, hogy minőségük megítéléséhez speciális képzésre és tapasztalatra van szükség, ezért a vevők nem tudják megítélni a piacon megjelenő szolgáltatások minőségét és erre építeni választásaikat. A szakmai tudás alkalmazása annyira függ az alkalmazás kontextusától, hogy állandó szakmai átgondolást, alkalmazkodást és speciális szakmai ,érzéket” igényel, (fingerspitzengefuhl of the professionals), s ez lehetetlenné teszi a sztenderdizációt, így a bürokratikus kontrollt is. Freidson szerint az értelmiségi szakemberek munkája nem sztenderdizálható, nem racionalizálható és nem tehető árucikké. 
Ugyanezt állítja Furlong is: „Mivel a szakemberek komplex és kiszámíthatatlan helyzetekkel szembesülnek, speciális tudásra van szükségük. Ahhoz azonban, hogy alkalmazhassák speciális tudásukat, autonómiára is szükségük van, mert csak annak birtokában tudnak legjobb belátásuk szerint cselekedni. Ha megkapják az autonómiát, akkor felelösséggel kell cselekedniük, és ezért szükséges, hogy együttesen alakítsák ki szakmai értékrendszerüket."(Furlong, 2000, 18-19. o.)

A neoliberális ideológiák összekevertek különféle logikákat, s az oktatást, az egészségügyet vagy a szociális ellátást is egyszerü fogyasztási cikként, szolgáltatásként kezelték, ahol a szülők és a tanulók szabadon választhatnak az intézmények között felállított rangsorok alapján. Ennek az lett a következménye, hogy a foglalkoztatók és menedzserek ítélték meg a tanári munka minőségét és felülről különféle fejlesztési programokat, továbbképzéseket írtak elő a tanárok számára. Evetts (2009) ezt szervezeti professzionalizmusnak (organizational professionalism) nevezi: „Az eredmény az, hogy a szakmai munkát nem a szakma gyakorlói kontrollálják, hanem a felügyelők és a menedzserek." (Evetts, 2009, 23. o.)

Evetts szemében a vevői elégedettségnek a menedzserek által müködtetett elszámoltathatóságra és auditálásra épülő rendszere veszélyezteti az értelmiségi szakmákba vetett közbizalmat, és erősen csökkenti azt az időt, amit a szakemberek a klienseikkel tudnak tölteni. Evetts a szervezeti professzionalizmussal szembeállítja a szakmai professzionalizmust, amelyet a következőképpen jellemez: ,...a szakmai csoportok közötti diskurzus, kollegiális tekintély, szakmai mérlegelés és a munka szakmai kontrollja, a kliensek és a munkáltatók bizalma a gyakorló szakemberek iránt, a gyakorló szakemberek által gyakorolt önkontroll, a szakmai etikai szabályok betartásának szakmai szervezetek és intézmények által gyakorolt ellenörzése". (Evetts, 2009, 23. o.)

Evetts, Freidson és Furlong egyetértenek abban, hogy az értelmiségi szakembereknek joguk legyen arra, hogy saját munkájukat maguk ellenőrizzék, maguk irányítsák a munkájuk végzéséhez szükséges tudás és készségek jellege, valamint a szakmai mérlegeléshez való joguk miatt. A tanításhoz szakmai ítélőképességre és szakmai intuíció alkalmazására van szükség (Atkinson és Claxton, 2000), amelyet lehetetlen sztenderdizálni. Azonban a szakmai kontroll és szakmai professzionalizmus megvalósítása a szakmai autonómia, a szakmai kompetencia és a szakma iránti bizalom szoros összekapcsolását teszi szükségessé.

\section{Az értelmiségi szakmák morális és altruista természete; a bizalom szerepe}

Annak érdekében, hogy megerősítsék a szakmai autonómia, a szakmai kompetencia és a bizalom közötti kapcsolatot, több szerző hangsúlyozza a professzionalizmus morális természetét. Ez az ötödik megközelítés az értelmiségi szakmák alapvető erkölcsi és altruista természetéből indul ki (Crook, 2008; Lunt, 2008). A szakmák morális és altruista természete a szakember és a kliens közötti szükségszerü hatal- 
mi egyensúlytalansághoz köthető. Az értelmiségi szakember szolgáltatása, mint például a tanár szolgáltatása a szülő és a gyermekek számára, szakmai autonómiát követel, amely a szakmák iránt táplált közbizalomra épül. A közbizalom alapja pedig a szakma etikai kódexének szigorú alkalmazása. Ezért a köz alkut köt az értelmiségi szakemberekkel (Lunt, 2008), amelyet az állam által lefektetett társadalmi szerződés testesít meg.

A társadalmi szerződésnek ,az a lényege, hogy az értelmiségi szakemberek több autonómiát kapnak, mint más társadalmi csoportok. Maguk határozhatják meg, kit engednek be a soraikba, maguk fegyelmezik tagjaikat és sokkal kevesebb korlátozással dolgozhatnak, mint a müvészetek, az üzleti élet vagy a kereskedelem területén müködők. Cserébe a közjót kell szolgálniuk, és meg kell felelniük a szakmai viselkedés, valamint fegyelem magas követelményeinek". (Skrtic, 1991, 87. o.)

Ez a szerződés adja egy-egy szakma társadalmi felhatalmazását, amely a köz és az állam értelmiségi szakemberekbe vetett bizalmára épül, ami viszont $a$ szakmák altruista természetén alapszik. Az értelmiségi szakember számára a szakmai siker mérőeszköze nem az, hogy mennyit keres, hanem az, hogy milyen szolgálatot tesz a köznek (Crook, 2008). A tanárok munkáját nem az teszi értékessé, hogy mennyi pénzt keresnek a tanítással, hanem a tanított gyermekek eredményeinek, tanulásuk minőségének javulása. Ez az altruista perspektíva teszi érthetővé, miért háborodik fel a közvélemény, ha politikusok, orvosok, iskolavezetők kiugró jövedelemmel rendelkeznek, vagy személyes karrierjük építésén fáradoznak. Az értelmiség számára a hangsúlyt a személyes integritás megörzésére és a másoknak tett szolgálatra kellene helyezni és nem a személyes érdekekre. Ilyen értelemben a tanítás hivatás.

Számos szerző hosszasan foglalkozott a bizalom fogalmával, és ennek során többféle típusát határozta meg, aszerint, hogy a bizalmi viszonyban rejlő kockázatot hogyan kezelik (Bottery, 2003; Byrk és Schneider, 2002; Nooteboom, 2006). A bizalom teóriák rámutatnak arra, hogy milyen fontossággal bír a köz és az állam bizalmának elnyerésében, és így a szakmai felhatalmazás jogosságának igazolásában a szakmai kompetencia, az integritás és a szakma képviselőinek elhivatottsága. A szakma képviselőnek óriási a felelősségük, meg kell felelniük a köz elvárásainak, és fel kell mutatniuk az elvárt kompetenciát, integritást és elhivatottságot. Ez a kötelessége a szakma egyes képviselőinek és a szakmai közösség egészének is. Például nyilvánosan számot kell adniuk a szakmai gyakorlatukról és eredményeikről bizonyítékok, kutatási eredmények alapján és a szakmai etikai szabályok, szankciók rendszerének alkalmazása által is. A szakmai etikai kódex szigorú alkalmazása biztosítja a feltétlenül szükséges védőhálót a köz és a szakmák közötti egyenlőtlen hatalmi viszonyok között. Az értelmiségi szakemberek elhivatottsága iránt megnyilvánuló közbizalom, Noteboom (2006) szerint, nagymértékben függ a szakemberek klienseik felé mutatott empátiáján. A szakember, a kliens vagyis a társadalom közötti kapcsolatokban sokat számít a szakmai gyakorlat egységes ér- 
telmezésének kialakítása. Ennek a közös értelmezésnek a kialakításában az értelmiségi szakember játssza a kulcsszerepet.

\section{A tanárok személyes kvalitásaira és a tanárképzésre vonatkozó tanulságok}

A tanári professzionalizmusra és a tanári szakmára vonatkozó diskurzust részben a tanárok elleni panaszok uralják. Ezek szerint egyrészt a tanárság nem szakma, s kibújik a kormány ellenőrzése alól is, ezért szükséges megerősíteni a szakma feletti bürokratikus kontrollt, az állami szabályozást és a menedzsment kontrollját is. A panaszok másik része szerint az állami intézkedések deprofesszionalizálják a tanárságot és demoralizálják a tanárokat. Ugyanakkor azt is látnunk kell, hogy ezt a diskurzust az angolszász szerzők és a brit-amerikai perspektívából írott cikkek uralják. Lehet, hogy a tanárok szakmaiságával kapcsolatos viták és dilemmák más kulturális kontextusokban sokkal kevésbé élesek.

Mindazonáltal látnunk kell, hogy a világ elvárásai a tanársággal és a tanárok szakmaiságával kapcsolatban magasak. Ezért el kell gondolkoznunk azon egyrészt, hogy melyek a tanári szakmaiság kulcselemei, másrészt azon is, hogy mit tehet a tanárképzés azért, hogy ezt a szakmaiságot kifejlessze a tanárjelöltekben.

A professzionalizmusról szóló szakirodalom áttekintése során egy sor alapvető vonás felszínre került. Bár a tanári professzionalizmus öt megközelítése erősen eltér egymástól, végső soron kiegészítik egymást, gazdagítják és komplexebbé teszik a tanári szakmaiság összképét. A tanári szakmaiság fö vonásai, amelyek a szakirodalom elemzése alapján kirajzolódtak, a következők:

1. Szakmai autonómia, a szakmai munka feletti monopólium és kontroll gyakorlása.

2. Beleszólás abba, ki léphet be a szakmába.

3. A szakmai értékek és a szakmai viselkedés feletti ellenőrzés gyakorlása a szakma etikai kódexén keresztül, és szankciók kiszabása szabályszegés esetén.

4. Szakmai szervezetek, amelyek a fenti mandátumok alapján eljárnak a szakma nevében.

5. A szakember morális integritásának és elhivatottságának hangsúlyozása.

6. Nyilvános elszámoltathatóság vállalása a szakmai teljesítményekért, eredményekért.

7. A szakmai munka mögötti elméleti és gyakorlati tudás.

8. A szakma tudásbázisának kiépítésében vállalt aktív szerep, kutatás, akciókutatás és introspektív kutatás révén.

9. A szakmához tartozók élethosszig tartó tanulása.

10. A kollégákkal és a többi érdekelt féllel történő együttmüködés.

11. Részvétel a szakma fejlesztésében, megújításában. 
12. Elkötelezettség az iránt, hogy a szakmának segíteni kell a közvéleményt és az államot a szakmai kérdések megértésében.

Ha a szakma ezen jellemzőit lefordítjuk az egyes szakemberekkel szemben támasztott követelményekre, akkor megalkotható egy tudáselemekből, készségekből, attitüdökből álló referenciakeret, amelyet fel lehet használni annak elemzésére, hogy a tanárképzési tantervek mennyiben szolgálják a tanári professzionalizmust. (Lásd a keretben lévő szöveget!)

A tanári professzionalizmushoz szükséges elemek:

- Tudás:

- alapos szaktárgyi tudás a tanulási/tanítási folyamat alapos ismerete (a pedagógiai kutatások legújabb, releváns eredményeinek ismerete)

- alapos társadalomismeret

- az oktatáspolitika és az oktatási rendszer alapos ismerete

- Készségek:

○ képes oktatási problémákat szélesebb közönséggel ismertetni, megvitatni

○ képes munkájának minőségéről számot adni a társadalom számára

○ képes az iskolai közösségén belül az iskola gyakorlatára vonatkozóan kutatásokat végezni

○ képes hozzájárulni a szakmai közösség együttmúködő tanulásához

- képes a pedagógiai kutatások eredményeit az iskola /osztályterem keretein belül innovációra használni

- Attitüdök:

○ elkötelezett a tanulók fejlődésének elősegítése mellett

- elkötelezett a szakma és a szakma müvelői iránt

- hajlandó hozzájárulni a szakma tudásbázisának fejlesztéséhez

- elkötelezett a szakma etikai kódexének betartása iránt, és ragaszkodik szakmai munkájának integritásához

- hajlandó munkájának minőségről elszámolni a külvilág felé

○ állandóan törekszik a szakmai fejlődésre

○ folytonosan javítja tanításának minőségét és törekszik az innovációra

Ha figyelembe vesszük egyrészt, hogy milyen erőteljes a társadalmi szándék a tanári munka javítására, másrészt hogy a társadalom milyen új, a tanításon túlmutató szerepelvárásokat támaszt a tanársággal szemben, akkor nem kerülhető el egy 
olyan tanárképzési tanterv kialakítása, amely túlmutat a minimális sztenderdeken, és segíti a kezdő tanárokat abban, hogy új tanári szerepeket vegyenek fel, hogy kiterjesszék a professzionalizmus határait. A bemutatott referenciakeret segíthet kifejleszteni, értékelni és megerősíteni egy ilyen tanárképzési tantervet.

Két, nemrég megjelent tanulmány is foglalkozik az EU tagállamaiban kialakított nemzeti sztenderdeknek és tanárképzési tanterveknek az elemzésével (Finnish Institute ..., 2009; Snoek et al., 2009). E tanulmányok megállapították, hogy immár kialakult a közmegegyezés arról, hogy milyen kompetenciákkal kell a tanároknak rendelkezniük. A legfontosabb kompetenciák: a tantárgyi tudás, a pedagógiai készségek, az osztálymunka irányítása, az elmélet és gyakorlat közötti összefüggések meglátása, a kooperáció és kollaboráció, az élethosszig tartó tanulás és kevésbé prominens helyen, a minőségbiztosítás, a mobilitás és a vezetői képességek.

A legtöbb kompetencia, amely a nemzeti sztenderdekben és a tanárképzési tantervekben fellelhetö, a mikro-, azaz az osztálytermi szintre koncentrál, tehát a tanítás és tanulásban betöltött primer tanári szerepre (European Commission, 2010). A vizsgált tantervek kevés teret szentelnek a másodlagos, a tágabb tanári szerepeknek. Egyik tanulmányban sem található adat arról, hogy a tanárképzési tantervekben explicit módon szerepelnének a következő elemek: a társadalom, az oktatáspolitika és az oktatási rendszer alapos ismerete; olyan a készségek és attitűdök, amelyek szükségesek ahhoz, hogy a tanárok el tudjanak számolni a tanítás minőségéről az oktatásban érdekelt társadalmi partnereknek - a szakfelügyelet elvárásainak teljesítésén kívül -; részvétel az oktatáspolitikai vitákban; elkötelezettség a tanári szakma és etikai kódexe iránt.

A tanárképzés tanterve elősegítheti, hogy ezeket az elemeket a jelöltek elsajátítsák a képzés során. Például azáltal, hogy bevonják a jelölteket a tanárképzési innovációkba, vagy olyan tevékenységekbe, amelyek a nyilvános elszámoltathatóságot szolgálják, vagy a külső társadalmi partnerekkel való együttmüködésbe, vagy azáltal, hogy ezeket a kvalitásokat és tevékenységeket maguk a tanárképzők modellálják a jelöltek számára.

\section{Irodalom}

Abbott, A. (1988): The system of professions: an essay on the division of expert labor. The University of Chicago Press, Chicago/London.

Atkinson, T., Claxton, G. (2000): The Intuitive Practitioner. Of the value of not always knowing what one is doing. Open University Press, Buckingham, Philadelphia.

Barber, M., Mourshed, M. (2007): How the world's best-performing schools come out on top. McKinsey, London.

Bottery, M. (2003): The Management and Mismanagement of Trust. Educational Management Administration leadership, 31(3), 245-261.

Byrk, A. S., Schneider, B. (2002): Trust in Schools. A core resource for improvement. Russell Sage Foundation, New York. 
CEDEFOP (2008): Future Skills needed in Europe, A medium term forecast. CEDEFOP, Thessaloniki.

Cochran-Smith, M., Lytle, S. L. (2009): Inquiry as a Stance. Practitioner research in the next generation. Teachers College Press, New York.

Crook, D. (2008): Some Historical Perspectives on Professionalism. In: Cunningham, B. (ed.): Exploring Professionalism. Institute of Education, London. 10-27.

Erixon, P. O., Frånberg, G., Kallós, D. (2001): Postgraduate Studies and Research in Teacher Education within the European Union. In: Erixon, P. O., Frånberg, G., Kallós, D.(eds.): The Role of Graduate and Postgraduate Studies and Research in Teacher Education Reform Policies in the European Union. Umea University, Umea. 47-60.

ETUCE (2008): Teacher Education in Europe. An ETUCE Policy Paper. Brussels: ETUCE. http://etuce.homestead.com/Publications2008/ETUCE_PolicyPaper_en_web. pdf (Retrieved 21 March 2010).

Etzioni, A. (ed., 1969): The Semi-Professions and their Organization. Free Press, New York.

European Commission (2005): Common European Principles for Teacher Competences and Qualifications. Brussels: European Commission. http://ec.europa.eu/education/ policies/2010/doc/principles_en.pdf(Retrieved 21 March 2010).

European Commission (2007): Improving the Quality of Teacher Education. Brussels: European Commission. http://ec.europa.eu/education/com392_en.pdf (Retrieved 21 March 2010).

European Commission (2010): Teachers' Professional Development - Europe in international comparison - An analysis of teachers' professional development based on the OECD's Teaching and Learning International Survey (TALIS). Office for Official Publications of the European Union, Luxembourg.

European Council (2006): Recommendation of the European Parliament and of the Council of 18 December 2006 on key competences for lifelong learning. Official Journal of the European Union, 394, 10-18.

European Council (2007): Conclusions of the Council and of the Representatives of the Governments of the Member States, meeting within the Council of 15 November 2007, on improving the quality of teacher education. Official Journal of the European Union C 300, 6-9.

European Council (2009): Council Conclusions on the professional development of teachers and school leaders. Official Journal of the European Union C 302. 6-9.

Evans, L. (2008): Professionalism, professionality and the development of education professionals. British Journal of Educational Studies, 1, 20-38.

Evetts, J. 2006. Introduction: Trust and professionalism: Challenges and occupational changes. Current Sociology, 4, 515-531.

Evetts, J. (2009): The Management of Professionalism: a contemporary paradox. In: Gewirtz, S., Manony, P., Hextall, I., Cribb, A. (ed.): Changing Teacher Professionalism. International trends, challenges and the way forward. Routledge, Oxon. 19-30.

Finnish Institute for Educational Research (2009): Teacher Education Curricula in the EU. Finnish Institute of Educational Research, Jyväskylä. 
Freidson, E. (2001): Professionalism: the third logic. University of Chicago Press, Chicago. Furlong, J. (2000): Intuition and the Crisis in Teacher Professionalism. In: Atkinson, T., Claxton, G. (eds.): The Intuitive Practitioner. Of the value of not always knowing what one is doing. Open University Press, Buckingham, Philadelphia. 15-31.

Gewirtz, S., Manony, P., Hextall, I., Cribb, A. (2009): Policy, Professionalism and Practice: Understanding and enhancing teachers' work. In: Gewirtz, S., Manony, P., Hextall, I. and Cribb, A. (eds.): Changing Teacher Professionalism. International trends, challenges and the way forward. Routledge, Oxon. 3-16.

Goodson, I., Hargreaves, A. (1996): Teachers' Professional Lives: Aspirations and Actualities. In: Goodson, I. - Hargreaves,A. (eds.): Teachers' Professional Lives. Falmer Press, London. 1-27.

Hanlon, G. (1998): Professionalism as Enterprise: Service class politics and the redefinition of professionalism. Sociology, 32, 42-63.

Hargreaves, A. (1994): Changing Teachers, changing times: teachers work and culture in a postmodern age. Cassell, London.

Hargreaves, A. (2000): Four ages of professionalism and professional learning. Teachers and Teaching: History and Practice, 6, 151-182.

Hattie, J. (2009): Visible Learning. A synthesis of over 800 meta-analyses relating to achievement. Routledge, London.

Hoyle, E. (1975): Professionality, professionalism and control in teaching. In: Houghton, V et al. (eds.): Management in education: The management of organizations and individuals. Ward Lock Educational in association with Open University Press, London.

Hoyle, E. and John, P. (1995): Professional Knowledge and Professional Practice. Cassell, London.

Koster, B. (2002): Lerarenopleiders onder de Loep. De ontwikkeling van een beroepsprofiel voor lerarenopleiders en het effect van het kennisnemen daarvan op hun zelfdiagnose. Universiteit Utrecht, Utrecht.

Larson, M. S. (1977): The Rise of Professionalism. University of California Press, Berkeley, CA..

Loughran, J. J., Hamilton, M. L., LaBoskey, V. K., Russell, R. (eds., 2004): International handbook of self-study of teaching and teacher education practices. Kluwer Academic Publishers, Dordrecht.

Lunt, I. (2008): Ethical Issues in Professional Live. In: Cunningham, B. (ed.): Exploring Professionalism. Institute of Education, London. 73-98.

Nooteboom, B. (2006): Forms, Sources and Processes of Trust. In: Bachmann, R. - Zaheer, A. (eds.): Handbook of Trust Research. Edward Elgar, Cheltenham, UK. 247-263.

OECD. (2005): Teachers Matters. Attracting, Developing and Retaining Effective Teachers - Final Report: Teachers Matter. OECD, Paris.

OECD (2007): Schooling for Tomorrow: Personalising education. OECD, Paris.

Ponte, P., Smeets, K. (2009): Action Research \& Teacher Leadership. Professional Development in Education, 35, 175-193. 
Power, S. (2008): The Imaginative Professional. In: Cunningham, B. (ed.): Exploring Professionalism. Institute of Education, London. 144-160.

Robertson, S. L. (1996): Teachers' work, restructuring and postfordism: constructing the new 'professionalism'. In: Goodson, I., Hargreaves, A. (eds.): Teachers' professional lives. Falmer Press, London. 28-55.

Skrtic, T. M. (1991): Behind Special Education: a critical analysis of professional culture and school organisation. Love Publishing Co., Denver CO.

Snoek, M., Swennen, A., van der Klink, M. (2009): The teacher educator: a neglected factor in the contemporary debate on teacher education. In: Hudson, B. (ed.): Proceedings of the TEPE 3rd Annual Conference Teacher Education Policy in Europe: Quality in Teacher Education. Umeå University, Umeå. 288-299.

Snoek, M. et al. (2009): Teacher quality in Europe: comparing formal descriptions. Paper presented at the ATEE conference 2009, Mallorca, August 2009.

Stenhouse, L. (1975): An Introduction to Curriculum Research and Development. Heinemann, London.

Verbiest, E. (2007): Professionals moeten het verdienen. Tijdschrift voor Hoger Onderwijs, 24, 239-248.

Whitty, G. (2008): Changing modes of teacher professionalism: traditional, managerial, collaborative and democratic. In: Cunningham, B. (ed.): Exploring Professionalism. Institute of Education, University of London, London. 28-49.

Fordította: Kimmel Magdolna 